side, it is proved by my statements that in this peculiarity both the Dresden Codex and the Palenque tablet differ from the Codex Troano-Cortez. For in the latter document the beginning of the sears is in the days kan, muluc, ix, cauac. This is proved by Codex Troano 23-20, when compared with the Dresden Codex 2.j-28. From this, and the general character of the Codex TroanoCortez, we may safely infer that this manuscript is of a later date than the Dresden Codex, and, perhaps, of a somewhat different locality.

Alluding to $9 \mathrm{C} 9 \mathrm{D}$ of the Palenque tablet, Professor Thomas remarks that on plate 48 and twice on plate 50 of the Dresden Codex no number-symbol is attached where the day is the twentieth of the month. This is obviously an erroneous statement; for in all the three cases named, and also in the Palenque tablet, there is a particular element attached to the hieroglyph of the month; and this particular element reveals itself as a graphic representation of the two eyes of the man (uinic), the substitute of the head of the slain, which $I$ have shown is the usual representation of the man (uinic) or the number twenty (uinal) (see Zeitschrift für Ethnologie, xIX., pp. 237-240.

With reference to Professor Thomas's last remarks, I will add that the symbol of the hand, as it is seen in the hieroglypth münik, is to be understood as a sign-language character for "to eat," and therefore has the phonetic value chi (compare the hieroglyph chikin, west). The figure of the outstretched hand occurs as a substitute for the hatchet, the probable expression of the sound ch'ac, "to cut." The proper phonetic and figurative value of the outstretched hand seems to be pax, "to beat."

Dr. Ed. Seler.

Steglitz, Germany, June, 1892.

\section{A Grape Vine Produces Two Sets of Leaves During the Same Season.}

THE scarcity of information upon the production of leaves at abnormal times furnishes an excuse for the following communication.

In the yard adjoining me there is a large grape-vine of several years' growth. A month ago this was a vigorous plant; the Jeaves were numerous and healthy, and the branches were loaded with grapes. About that time numerous caterpillars attacked the vine, and in less than a week there was not a leaf left upon it. Numerous petioles, bearing fragments of the principal veins, were all that remained of the foliage. The grapes began to shrivel, and the smaller twigs to show signs of premature decay.

But the end was not yet. About a week after the leaves were destroyed, buds located at the nodes - buds which normally would have remained dormant until next year - began to develop a second foliage. Although not yet full-grown, these leaves have given a new lease of life to the vine. The few shriveled bunches of grapes that have survived the great draught upon their moisture are rapidly regaining their plumpness. The plant is itself again.

One fact is worth noting; although almost four weeks have elapsed since the leaves were destroyed, the petioles remain attached to the stems. These petioles are as green as ever, and in most cases they retain short bits of the principal veins of the leaves. Near the petioles these veins are green, but their free extremities are shriveled and brown.

C. H. TURNER.

University of Cincinnati, July 10.

\section{BOOK-REVIEWS.}

The Stone, Bronze, and Iron Ages. A Popular Treatise on Early Archoeology. By JoHN Hunter-Duvar. London, Swan Sonnenschein \& Co. New York, Macmillan \& Co. $285 \mathrm{p}$. $\$ 1.25$.

As the author claims for this book no other character than that of a popular treatise, it will be sufficient to inquire whether it is a fair representation of the most approved views of the science, as expressed by those who have made it a speciality. This it usually is, although the author, who never quotes his authorities, has inserted opinions here and there which are certainly not those generally accepted. For instance, he understates the artistic relics of the Palæolithic period; he assumes?that the weapons of the river drift were more ponderous than those of later date; he asserts that no idols have been recovered from the stations of that epoch; and that no human remains have been unearthed from the European kitchen-middens. Our countrymen will also be surprised to learn that Mound City is another name for St. Louis (p. 142).

In spite of such slight blemishes, the book can be recommended as a convenient and usually accurate manual of this attractive science. It begins at the beginning, tracing the story of man from early post-tertiary times through the drift and cave periods in Europe, and the neolithic, bronze, and iron ages. There are special chapters on the lake-dwellers, fossil man, myths, pottery, sepulture, and art, and one on the mound-builders of the Ohio Valley.

\section{Journal and Proceedings of the Royal Society of New South} Wales. Vol. XXV. 1891. 348 p.

THE creditable publications of this active society have already reached their twenty-fifth volume, and it comes replete with entertaining material. Several reports from the Sydney Observatory on celestial photography will have interest for the astronomer; articles on Kaolinite and the microscopic structure of Australian rocks will attract the geologist; the causes of death among sheep and rabbits in Australia will be welcome to the agriculturist; the folk-lorist will turn with pleasure to Mr. Pratt's translations of songs and myths from Samoa; while the mechanicians and cranks will be glad to read about a ship which can be propelled by the action of the waves alone, and a flying machine which is to navigate the sky by the motive power of compressed air. This is certainly a varied repast, at which each may find a dish to his liking.

\section{AMONG THE PUBLISHERS.}

A work on the "Migration of Birds," by Charles Dixon, will shortly be published by Messrs. Chapman \& Hall.

- Messrs. Longmans, Green, \& Co. have issued a third edition, revised and enlarged, of Professor E. A. Schäfer's “ Essentials of Histology." The intention of the author is to supply students with directions for the microscopical examination of the tissues.

- A "Dictionnaire de Chimie industrielle" is being issued in parts, under the direction of A. M. Villon, by the "Librairie Tignol." It gives an account of the applications of chemistry to metallurgy, agriculture, pharmacy, pyrotechnics, and the various arts and handicrafts.

- Henry Stevens \& Son, 39 Great Russell Street, London, promise for next month Henry Harisse's " Discovery of North America: a critical, documentary, and historic investigation, with an essay on the early cartography of the New World," etc. This important work by the foremost investigator in the field will make: a quarto volume of 800 pages, with 23 plates and many illustrations in the text, and will be issued to subscribers in three styles, ranging in price from $£ 5$ to $£ 1216 \mathrm{~s}$. Only 360 copies are to be printed.

- The American Society for the Extension of University Teaching, Philadelphia, has just issued five monographs on various phases of the university extension movement, being reprints from the Proceedings of the Society. These are: "The Place of University Extension in American Education," by William T. Harris, U. S. Commissioner of Education; "The Organization and Function of Local Centres," by Michael E. Sadler, secretary of the Oxford University Extension Delegacy; "The Church and University Extension," by Rev. John S. Macintosh; " The Ideal Syllabus," by Henry W. Rolfe; and "The University Extension Class," by Edward T. Devine.

- With the number for July, the "Annals" of the American Academy of Political and Social Science begins its third volume. The first article in the current number is entitled "Cabinet Government in the United States." It is by Professor Freeman Snow of Harvard, and is an answer to the many pleas for the adoption 